\title{
Density and Size Distribution of the Sea Cucumber, Holothuria scabra (Jaeger, 1935), at Six Exploited Sites in Mahout Bay, Sultanate of Oman
}

\author{
Khalfan M. Al-Rashdi ${ }^{1}$, Michel R. Claereboudt ${ }^{*}$ \\ and Saud S. Al-Busaidi ${ }^{3}$
}

${ }^{1}$ Ministry of Fisheries, Aquaculture Center, Oman

${ }^{2}$ Department of Marine Science and Fisheries, College of Agricultural and Marine Sciences, Sultan Qaboos University, P.O. Box 34, Al-Khod 123, Muscat, Sultanate of Oman

${ }^{3}$ Ministry of Agriculture and Fisheries, Marine Science and Fisheries Center, Oman

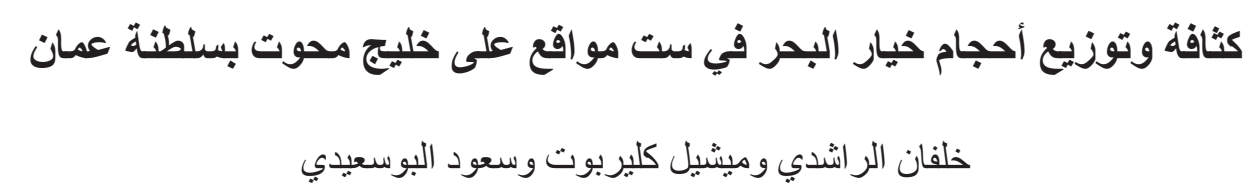

الخلاصة: تم إجر اء مسح سريع لمعرفة كثافة وتوزيع أحجام خيار البحر في ست مو اقع تم استغلالها على خليج محوت (خليج غبة الإنة

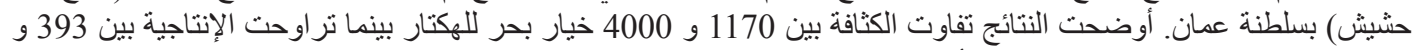

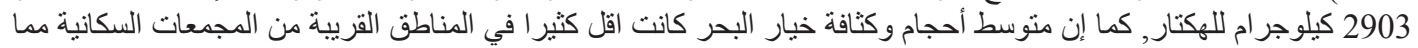

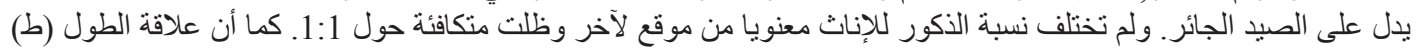

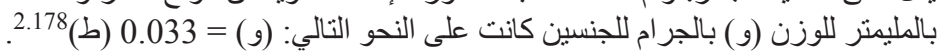

ABSTRACT: A rapid survey of the density and size distribution of recently exploited populations of Holothuria scabra in Mahout Bay (Ghubbat Hashish Bay) was carried out at six fishing sites. The results showed that population densities varied between 1170 and 4000 individuals ha- ${ }^{1}$ and biomass ranged between 393 and $2903 \mathrm{~kg} \mathrm{ha}^{-1}$. The mean size of sea cucumbers and population densities were much lower in populations closer to human settlements, suggestive of overfishing. The sex ratio was estimated to be $1: 1$ and the size distributions of males and females did not differ significantly. The length-weight relationship for both sexes was calculated as $\mathrm{W}(\mathrm{g})=0.033$ Length $(\mathrm{mm})^{2.178}$.

Keywords: Sea cucumber, Holothuria scabra, density, size, sex ratio, Oman.

\section{Introduction}

Sea cucumbers (Holothuroidea) inhabit sheltered shallow-water sediments in all tropical and temperate oceans, but their greatest abundance and diversity occur in the tropical Indo-Pacific region (Conand, 2004). They have been exploited for at least 1000 years, particularly around India, Indonesia and the Philippines, mainly for bêche-de-mer (or trepang), the processed dried body-wall which commands high prices on Asian markets (Conand and Byrne, 1993; Conand, 2004; Ferdouse, 2004). Although the bulk of bêche-de-mer production still originates from the western Pacific ( $>14000$ tons/yr) a considerable amount (>1000 tons/yr) comes from the western Indian Ocean (FAO Area 51) (FAO, 2003). The fisheries for sea cucumbers in the western Indian Ocean extend from South Africa in the south to the Arabian Peninsula in the north (Conand and Byrne, 1993), and overviews are available for Madagascar (Rasolofinirina and Jangoux, 2004), Tanzania (Kithakeni and Ndaro, 2002; Mmbaga and Mgaya, 2004), Seychelles (Aumeerruddy and Rondolph 


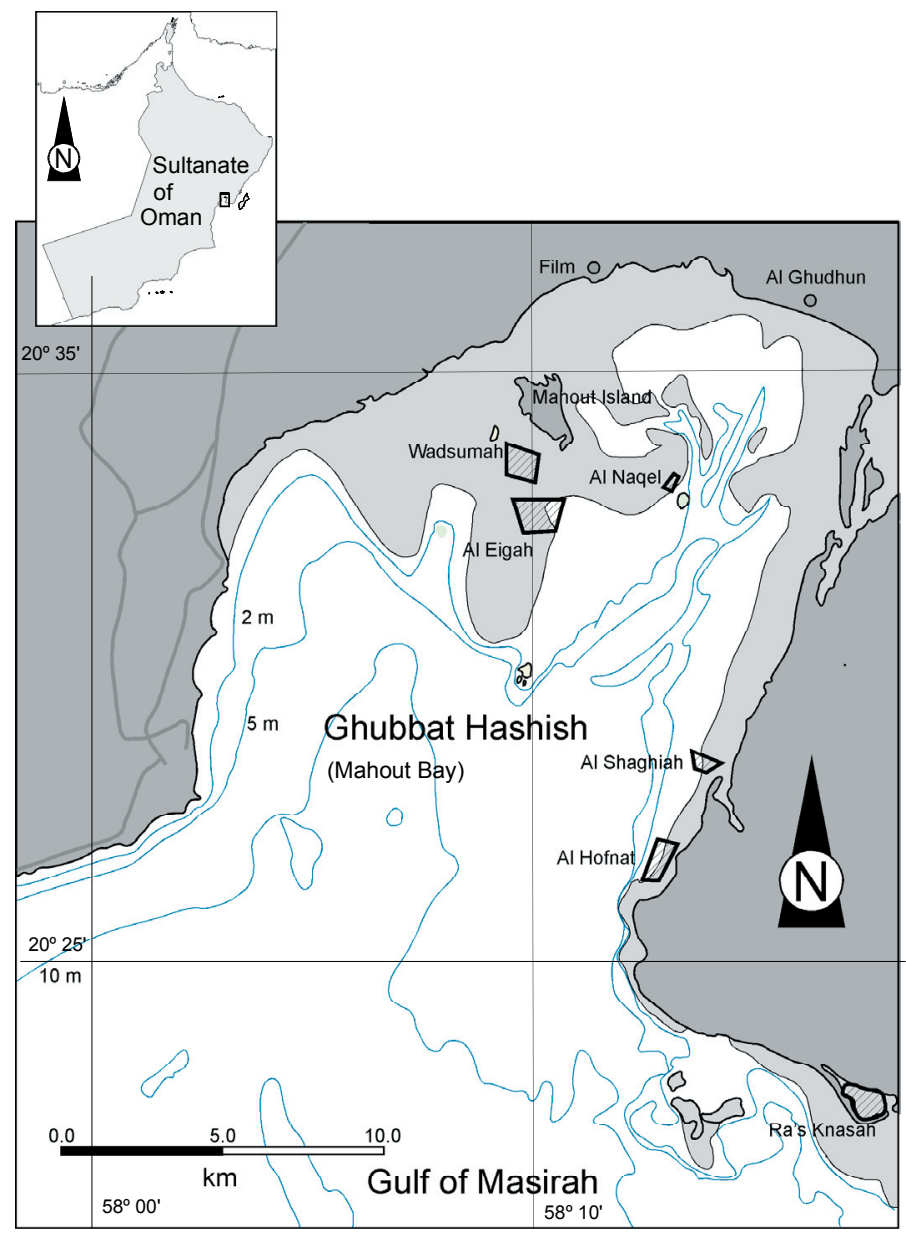

Figure 1. Map of Mahout Bay (Ghubbat Hashish). The six fishing grounds are represented by hatched areas with a thick border.

Payat, 2004) and the Red Sea coast of Egypt (Lawrence et al., 2004). Very few countries (and none along the rim of the western Indian Ocean) have consistent fisheries management plans for sea cucumbers, and hence there is a constant threat of overexploitation wherever they are fished (Conand, 2001).

A fishery for Holothuria scabra, commonly known as sandfish, and one of the most valuable species in the trade, (Conand and Byrne, 1993) has recently begun in Mahout Bay, along the Arabian Sea coast of the Sultanate of Oman (Al-Rashdi et al., 2007). Artisanal fishers collect H. scabra by wading in shallow areas at low tides. The body walls of the animals are locally processed and exported in dry form, mainly to the United Arab Emirates. The fishery saw a significant and rapid increase in 2004 and 2005 (Al-Rashdi et al., 2007), much like that experienced in most other countries where H. scabra is fished (Uthicke and Conand, 2005). Anecdotal evidence suggests a reduction in the size of sea cucumbers captured by fishers in Mahout Bay.

Very little information is available on the fishery, biology and ecology of H. scabra and other holothuroids along the Arabian Sea coast of the Sultanate of Oman (Al-Rashdi et al., 2007). A field survey was therefore undertaken to investigate the densities and size distribution of sea cucumbers at six sites in Mahout Bay, in relation to fishing intensity. 


\section{Materials and Methods}

The study area covered Mahout Bay (Ghubbat Hashish Bay; $20^{\circ} 27^{\prime} \mathrm{N} 58^{\circ} 10^{\prime} \mathrm{E}$ ), where the only known fishery for $\mathrm{H}$. scabra in the Sultanate of Oman takes place (Fig. 1). The semi-sheltered bay forms the innermost part of the Gulf of Masirah and covers approximately $320 \mathrm{~km}^{2}$ (Fig. 1). The maximum depth in the south of the Bay is around $10 \mathrm{~m}$. However, most of its surface area is less than $5 \mathrm{~m}$ in depth. It is micro-tidal and relatively protected from the severe wave climate generated by the monsoon winds during the summer.

Three sites were examined in each of the six fishing grounds: Al Eigah, Wadsumah, Al Naqel, Al Shaghiah, Al Hofnat and Ra's Knasah (Fig. 1). Three of these fishing grounds (Al Eigah, Wadsumah and Al Naqel) are located on shallow sand banks in the northern part of Mahout Bay near the small island of Mahout. During spring low tides, almost $80 \%$ of these sand banks are exposed to form large barrier flats which are located within 15 min by boat from the nearest village, Al Ghudhun, and thus easily accessible. In contrast, the fishing grounds located in the southeastern area of Mahout Bay (Al Shaghiah, Al Hofnat and Ra's Knasah) are coastal shallows located about a 1 hour drive (dirt track) from $\mathrm{Al}$ Ghudhun and thus more difficult to access.

The six fishing grounds were ranked in accessibility according to their distance-time from Al Ghudhun as a proxy for fishing effort. The approximate size of each of the fishing grounds was obtained by plotting their limits on a map from the coordinates provided by local fishermen.

At each fishing ground, three rectangular transects $(2 \mathrm{~m} \times 50 \mathrm{~m})$ were laid on the sediment with measuring tapes during low tide. Two investigators collected all sea cucumbers found within the $100 \mathrm{~m}^{2}$ of each transect, recording simultaneously the type of substrate, vegetation and other macrofauna. Three sediment samples per transect were collected and analyzed for granulometry (dry sieving) and organic matter (wet oxidation).

Length and weight data were collected for each sea cucumber after allowing the sea cucumber to relax in water for $5 \mathrm{~min}$. Total length from mouth to anus was measured to the nearest $0.5 \mathrm{~cm}$ with a flexible ruler. Wet weight was measured to the nearest $5 \mathrm{~g}$ immediately after removing the animal from the water to avoid evisceration. For a sub-sample of 151 specimens chosen randomly from all six fishing grounds, expulsion of the gonads was triggered by squeezing the body and sex identification performed based on the general appearance (color and texture) of the gonads.

\section{Results}

\section{Habitat}

All six sites consisted of mostly sands (mean $=80.9 \%$; Fig. 2) with a highly variable contribution of medium and coarse/fine sand fractions $(>250 \mu \mathrm{m}-<250 \mu \mathrm{m})$ within sites and between sites. Concentration in organic material averaged $0.62 \mathrm{mg} \mathrm{g}^{-1}$ with little variation between the sampling sites.

The six sites showed various abundances of sea grasses (Syringodium isoetifolium, Halophila ovalis, Halodule uninervis and Thalassodedron ciliatum) although in none of the sites were these species dominant. Various mollusks (Pinna sp., Plagiocardium pseudolima, Murex scolopax) and non-holothuroid echinoderms (Astropecten sp., sand dollars) were also found in abundance while surveying for sea cucumbers. In the shallow water, small stingrays (Taeniura lymma) and guitar sharks (Rhinobatos spp.) were encountered but not quantified.

\section{Population size structure}

Four species of holothuroids were recorded during the survey (H. scabra, H. atra, H. edulis and $H$. leucospilota) although $H$. scabra represented the great majority of the observed specimens. H. scabra had several intergrading color morphs with the lower surface of the animal varying from nearly black to nearly white and the upper surface mottled grey with transverse white markings (Fig. 3).

Population densities ranged from 1770 individuals $\mathrm{ha}^{-1}$ or $\left(393 \mathrm{~kg} \mathrm{ha}^{-1}\right)$ in Al Eigah to 4000 individuals $\mathrm{ha}^{-1}$ or $2903 \mathrm{~kg} \mathrm{ha}^{-1}$ in Ra's Knasah (Table 1). When multiplied by the estimated surface area of the fishing grounds, these values translates into a live biomass of 9.75 tons in Al Naqel to 272.85 tons in Ras-Knasah (Table 1).

The smallest observed H. scabra was $85 \mathrm{~mm}$ (Al Eigah) and the largest was $395 \mathrm{~mm}$ (Ra's Knasah). Length distributions varied considerably between fishing grounds (Fig. 4). The smallest individuals were 


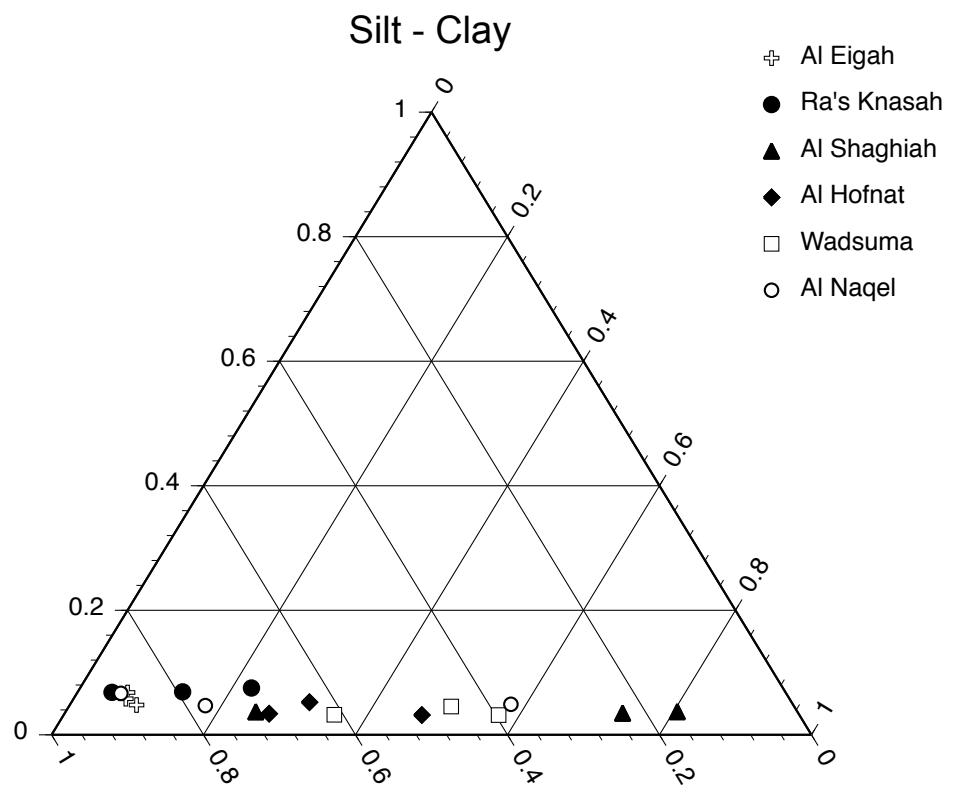

Fine Sand

Coarse -Medium Sand

Figure 2. Triangular diagram of relative contribution of medium and coarse sand $(>250 \mu \mathrm{m})$, fine sand (64$250 \mu \mathrm{m})$ and silt-clay $(<64 \mu \mathrm{m})$ to the sediment found in each of three replicates from each of the 6 sampling sites near Mahout Island.

found in Al Eigah and Wadsumahh where most of the measured specimens were $<160 \mathrm{~mm}$. On the other hand, individuals in Ra's Knasah were much larger, with $78 \%$ of the sea cucumbers larger than $200 \mathrm{~mm}$. A Chi-square analysis indicated that these differences in length distributions between fishing grounds were significant (chi-square $=388, \mathrm{DF}=25, \mathrm{p}<0.001$ ). There was also an inverse relationship between fishing ground accessibility and mean sea cucumber length (Table 1, Spearman $r=0.81, p<0.05$ ).

The sex ratio pooled from all sites revealed 77 males and 74 females. A Chi-square analysis with Yates' correction indicated that this ratio was not significantly different from 1:1 (Chi-square $=0.06$, $\mathrm{DF}=1, \mathrm{p}=0.80$ ). Furthermore, the distribution of sizes (Fig. 5) was also similar between males and females (Chi-square $=1.28, \mathrm{DF}=5, \mathrm{p}=0.93$ ).

A power curve was fitted to the length-weight data $\left(\mathrm{W}(\mathrm{g})=0.033\right.$ Length $\left.(\mathrm{mm})^{2.178}\right)$, and the relationship observed was highly correlated $\left(\mathrm{R}^{2}=0.80, \mathrm{p}<0.0001\right.$; Fig. 6).

\section{Discussion}

The habitat in which H. scabra was found was typical for this species which prefers low energy habitats within embayments (Conand, 1989) with sparse seagrasses (Jupp et al., 1996). Although probably biased by a sampling protocol focusing on existing fishing grounds, the observed population densities $\left(1770-4000\right.$ ind ha $\left.^{-1}\right)$ were at the high end of the range reported for this species (Table 2). The biomass recorded in our survey was also high in comparison to that observed in the Great Lagoon in New Caledonia (240 kg ha-1; Conand, 1989) but somewhat lower than that recorded in pre-exploitation populations in the Red Sea (3400 - $4670 \mathrm{~kg} \mathrm{ha}^{-1}$; Hasan, 2005). The negative correlation found between accessibility (presumed as a proxy for fishing effort) and mean length suggests that H. scabra populations in Mahout Bay area are already under significant fishing pressure, only three years after the commencement of the fishery. Similar trends of reduced population density and size 


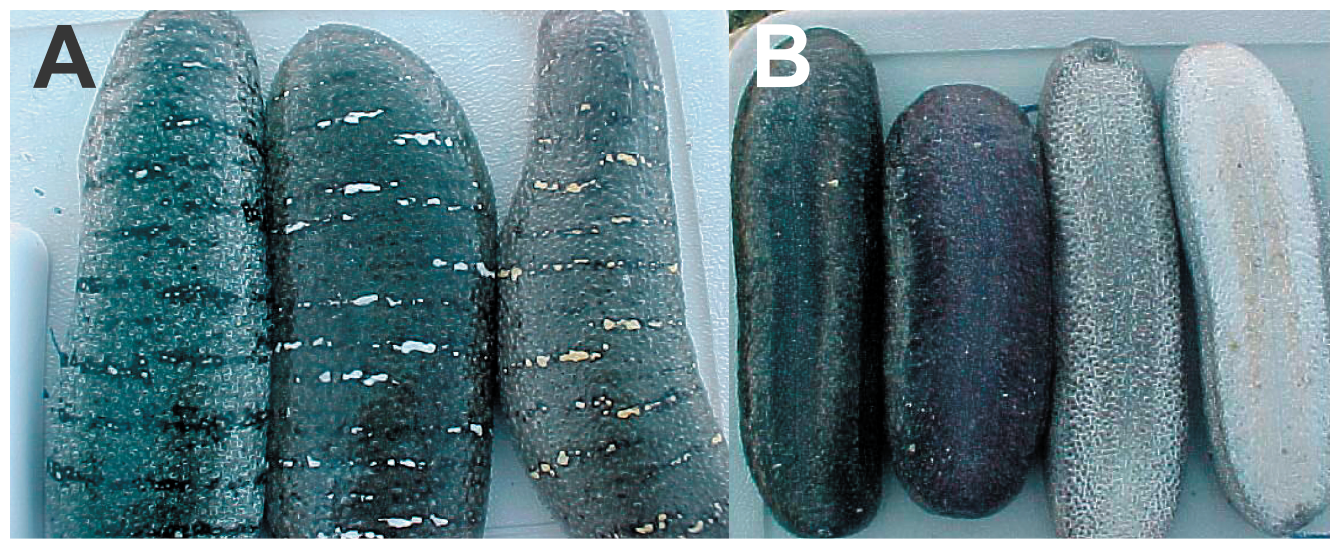

Figure 3. Various color morphs of Holothuria scabra near Mahout. A. Dorsal view. B. Ventral view.

distribution were found in populations sampled on "protected" and "exploited" reefs in the Great Barrier Reef (Uthicke and Benzie, 2000). The particularly low values observed in Al Eigah in terms of density, mean length and biomass, suggest that fishing activities have already started to alter the population structure in this easily accessible area. Furthermore, assuming a length at first maturity around $200 \mathrm{~mm}$, as in other population of the same species around the world (Harriot, 1980; Shelly, 1981; Kithakeni and Ndaro, 2002; Hasan, 2005), most animals found in Al Eigah would be immature, placing this population at

Table 1. Site characteristics and Holothuria scabra population estimates for the six surveyed sites. Surface areas were estimated from the limits of the fishing grounds indicated by the fishermen. Accessibility was calculated and ranked by a measure of distance/time from Al-Ghudhun ( 1 is closest and 6 furthest from the town) and can be considered as a proxy for fishing effort. Processed biomass is the potential total yield of the site in processed bêche-de-mer assuming a processing loss of $95 \%$ of the wet weight (Conand, 1979). When available, Standard Deviation is presented in parenthesis.

\begin{tabular}{lcccccc}
\hline & $\begin{array}{c}\text { Al } \\
\text { Eigah }\end{array}$ & Wadsumah & $\begin{array}{c}\text { Al } \\
\text { Naqel }\end{array}$ & $\begin{array}{c}\text { Al } \\
\text { Shaghiah }\end{array}$ & Al Hofnat & $\begin{array}{c}\text { Ra's- } \\
\text { Knasah }\end{array}$ \\
\hline Site characteristics & & & & & & \\
Accessibility (rank) & 1 & 2 & 3 & 4 & 5 & 6 \\
Medium and coarse sand (\%) & 7.56 & 52.06 & 27.56 & 61.367 & 38.333 & 14.03 \\
Mean grain size (Phi) & 1.96 & 1.44 & 1.75 & 1.34 & 1.60 & 1.95 \\
Surface area (ha) & 120 & 80 & 9 & 95 & 70 & 95 \\
Sea cucumber population estimates & & & & & & \\
Average Length (mm) & $166(37)$ & $190(33)$ & $192(36)$ & $177(23)$ & $205(26)$ & $268(31)$ \\
Pop. Density Ind/ha & 1770 & 2970 & 2966 & 2200 & 2530 & 4000 \\
Pop. Biomass kg/ha & 393 & 1074 & 1074 & 438 & 829 & 2903 \\
Total biomass (tons) & 47.16 & 85.92 & 9.661 & 41.16 & 57.820 & 275.78 \\
Processed biomass (tons) & 2.35 & 4.38 & 0.49 & 0.66 & 2.99 & 13.64 \\
\hline
\end{tabular}



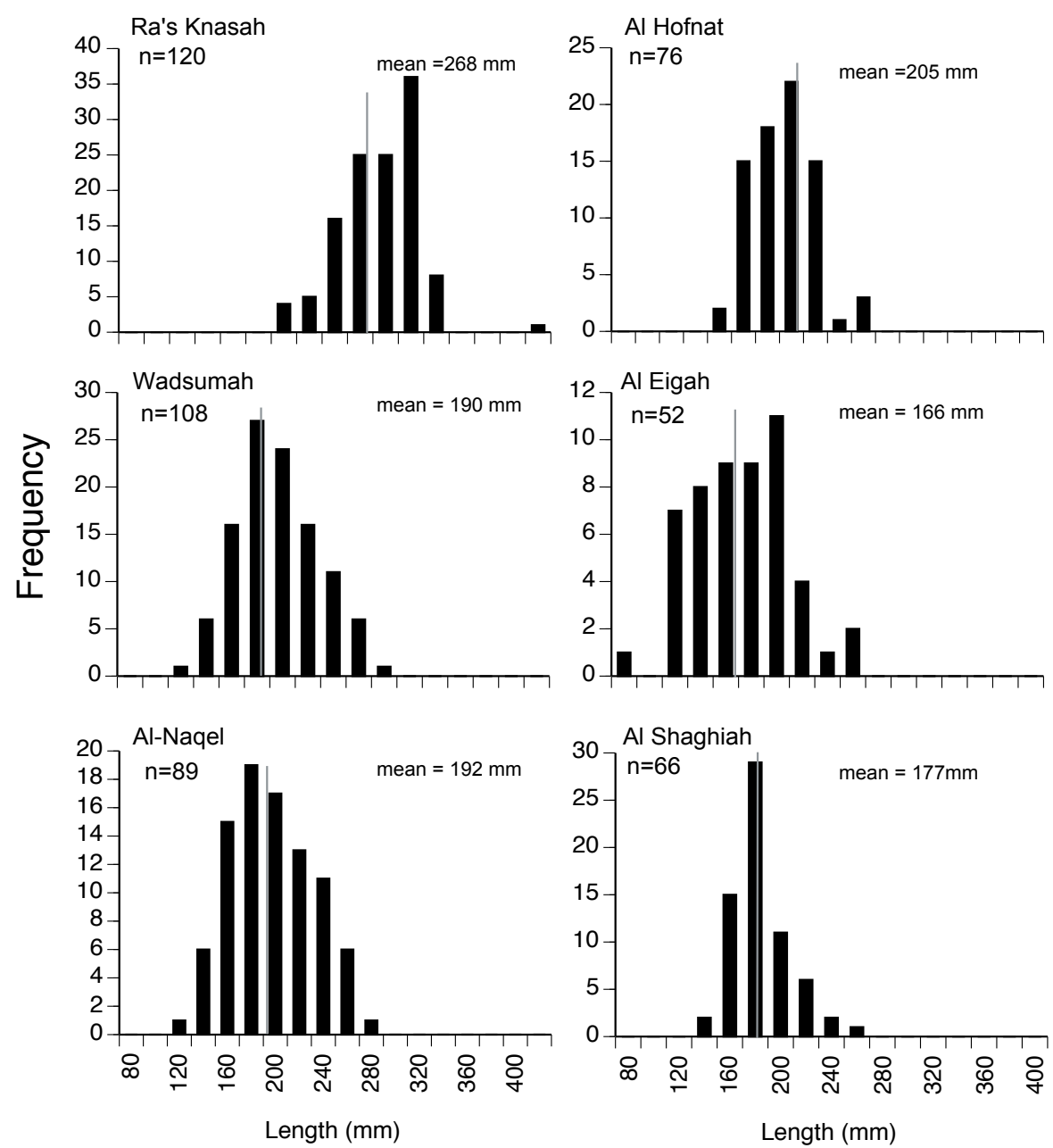

Figure 4. Holothuria scabra length frequency distribution for all six sampling sites. The total number of individuals collected in the $3 \times 100 \mathrm{~m}^{2}$ quadrats at each site is indicated as $n$. Note that the frequency scale is not identical on all graphs.

high risk of recruitment overfishing. Overfishing is easily achieved in wild populations of sea cucumbers and unmanaged exploitation most often results in the demise of the fishery (Conand and Byrne, 1993; Hasan, 2005; Uthicke and Conand, 2005).

The relative number of males and females in the overall Mahout population of $H$. scabra were statistically identical and thus consistent with a sex ratio of 1:1 as found in most species of Holothuroids (Conand, 1989; Uthicke, 1997; Hamel et al., 2001; Hasan, 2005).
The observed length-weight power relationship is consistent with most studies on sea cucumber growth. The allometric coefficient (2.18) calculated for the Omani population was however lower on average than the few published values for this species in Vietnam (2.84; Pitt and Duy, 2004) or in New Caledonia (2.28; Conand, 1990). This suggests that for a given length, the individuals collected in Oman were leaner than those collected either in Vietnam or new Caledonia. These differences could correspond to actual biological differences in relation to the strong seasonality of the environmental conditions related to the summer 


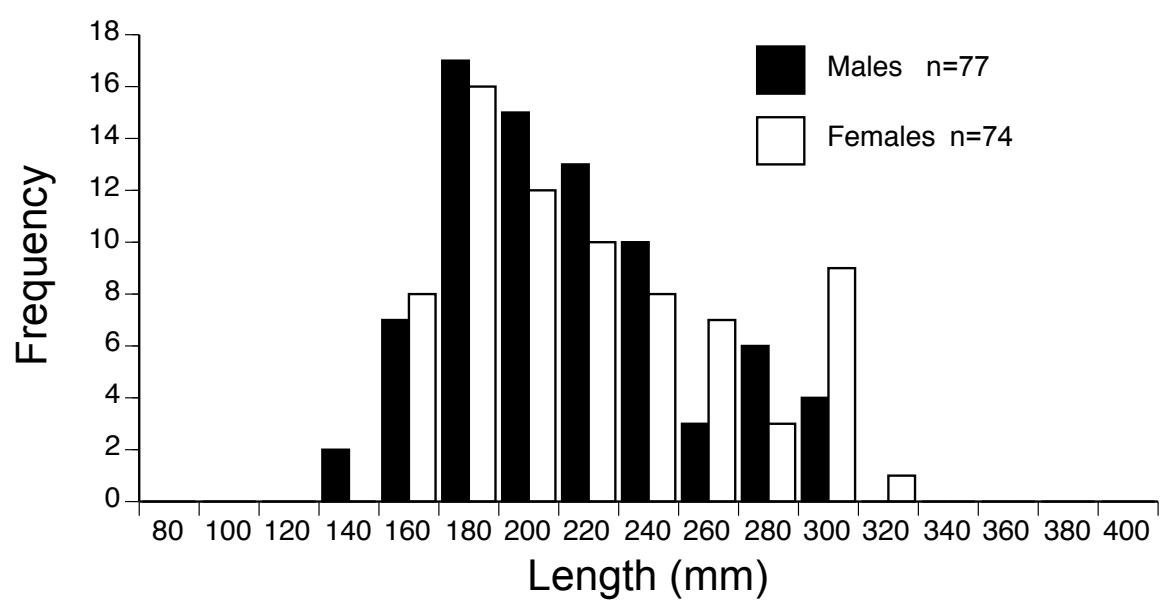

Figure 5. Pooled size distributions of males and females collected from all six fishing grounds.

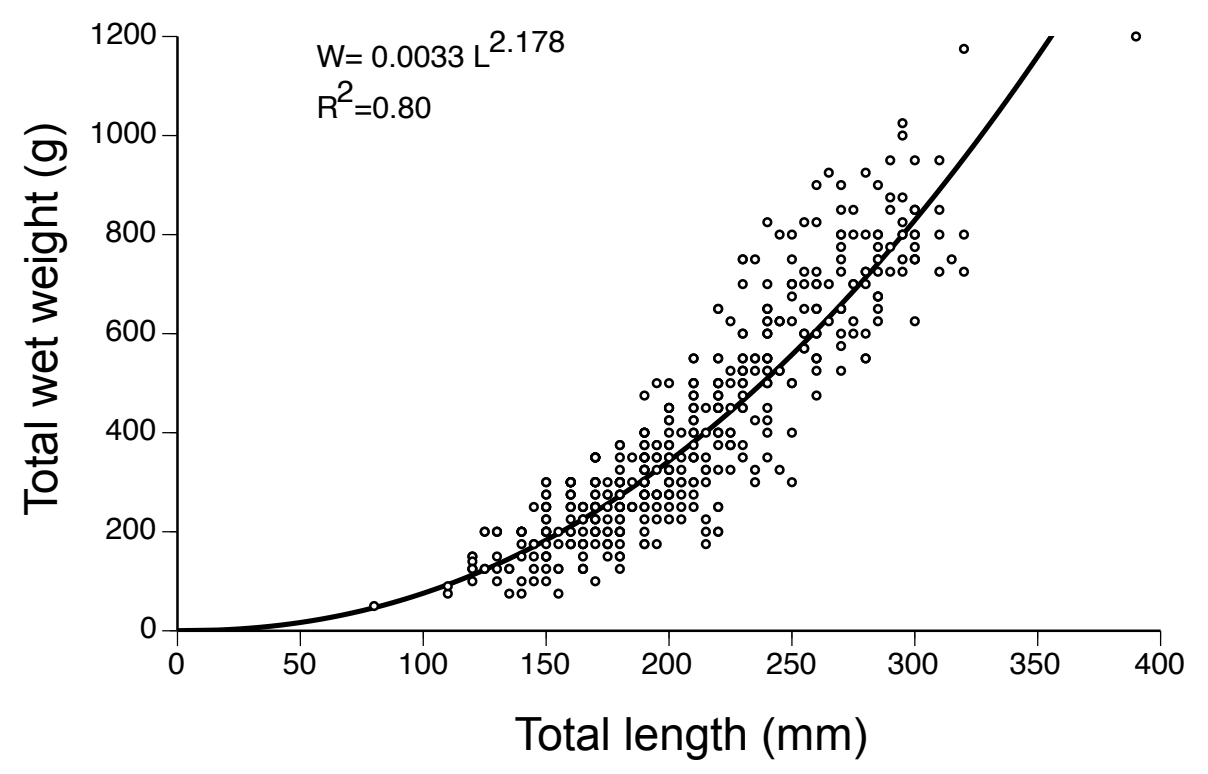

Figure 6. Length—wet-weight relationship for both sexes of Holothuria scabra in Mahout Bay. 
Table 2. Population densities of Holothuria scabra.

\begin{tabular}{|c|c|c|}
\hline Location & $\begin{array}{l}\text { Population } \\
\text { density } \\
\left(\text { Ind } \text { ha }^{-1}\right)\end{array}$ & Source \\
\hline $\begin{array}{l}\text { Mahout Bay } \\
\text { New Caledonia }\end{array}$ & $\begin{array}{l}1770-4000 \\
10-6000\end{array}$ & $\begin{array}{l}\text { This Study } \\
\text { (Conand, 1989) }\end{array}$ \\
\hline Solomon Islands & $20-220$ & $\begin{array}{l}\text { (Mercier et al., } \\
\text { 2000) }\end{array}$ \\
\hline India & $40-200$ & (James, 1994) \\
\hline Egypt & $0-158$ & $\begin{array}{l}\text { (Lawrence et } \\
a l ., 2004 \text { ) }\end{array}$ \\
\hline
\end{tabular}

monsoon (June-Sept) or might simply be due to slight differences in procedures to estimate either the total weight or the total length of the sea cucumbers.

\section{Recommendations}

At present, sea cucumber fishing in Oman is not regulated. To establish proper management and regulation of the fishery, studies of the biology and ecology, particularly reproductive biology and population dynamics in relation to the environment, are needed.

\section{Acknowledgements}

The authors wish to acknowledge the financial contributions of the Ministry of Agriculture and Fisheries and the Oman Fisheries Company. We also thank the personnel of the Al-Wusta and AshSharqiyah regional offices of the Directorate General of Fisheries for their assistance in the field.

\section{References}

Al-Rashdi, K. M., S.S. Al-Busaidi and I.H. AlRassadi. 2007. Status of the sea cucumber fishery in the Sultanate of Oman. SPC Beche de mer Information Bulletin 25:17-21.

Aumeerruddy, R. and R.R. Payat. 2004. Management of the Seychelles sea cucumber fishery: status and prospects. In: Advances in Sea Cucumber Aquaculture and Management, A. Lovatelli, C. Conand, S. Purcell, S. Uthicke, J.F. Hamel and A. Mercier (Editors), pp 239-246. Geneva: FAO Fisheries Technical Paper.

Conand, C. 1979. Bêche-de-mer in New Caledonia: weight loss and shrinkage during processing in three species of holothurians. South Pacific Commission Fisheries Newsletter 19:14-17.
Conand, C. 1989. Les holothuries aspidochirotes du lagon de Nouvelle Calédonie: biologie, écologie et exploitation. Paris: ORSTOM. 393 pp.

Conand, C. 1990, The fishery resources of Pacific island countries. Part 2: Holothurians. In: FAO Fisheries Technical Paper, p. 143. Geneva: FAO.

Conand, C. 2001. Overview over the last decade of sea cucumber fisheries: what possibilities for a durable management? In: Echinoderms 2000, M. Baker (Editor), pp 333-344. Rotterdam: Swets and Zeitlinger.

Conand, C. 2004. Present status of world sea cucumber resources and utilization: An international overview. In: Advances in Sea Cucumber Aquaculture and Management, A. Lovatelli, C. Conand, S. Purcell, S. Uthicke, J.F. Hamel and A. Mercier (Editors), pp 13-23. Geneva: FAO Fisheries Technical Paper.

Conand, C. and M. Byrne. 1993. A review of recent developments in the world of sea cucumber fisheries. Marine Fisheries Review 55:1-13.

FAO. 2003. FAO Yearbook. Fishery Statistics: Capture production 2001. Vol. 92(1). Rome. $627 \mathrm{pp}$.

Ferdouse, F. 2004. World markets and trade flows of sea cucumber/Beche-de-mer In: Advances in Sea Cucumber Aquaculture and Management, A. Lovatelli, C. Conand, S. Purcell, S. Uthicke, J.F. Hamel and A. Mercier (Editors), pp 101-117. Geneva: FAO Fisheries Technical Paper.

Hamel, J.F., C. Conand, D.L. Pawson and A. Mercier. 2001. The sea cucumber Holothuria scabra (Holothuroidea : Echinodermata): Its biology and exploitation as beche-de-mer. Advances in Marine Biology 41:129-223.

Harriot, V.J. 1980. The ecology of holothurian fauna of Heron Reef and Moreton Bay. MSc, University of Queensland.

Hasan, M. H. 2005. Destruction of a Holothuria scabra population by overfishing at Abu Rhamada Island in the Red Sea. Marine Environmental Research 60:499-511.

James, D.B. 1994. Seed production in sea cucumbers. Aquaculture International 1:15-26.

Jupp, B.P., M.J. Durako, W. J. Kenworthy, G.W. Thayer and L. Schillak. 1996. Distribution, abundance and species composition of seagrasses at several sites in Oman. Aquatic Botany 53: 199-213.

Kithakeni, T. and S.G.M. Ndaro. 2002. Some aspects of sea cucumber, Holothuria scabra (Jaeger, 1935), along the coast of Dar es Salam. Western Indian Ocean Journal of Marine Science 1:163-168. 
Lawrence, A.J., M. Ahmed, M. Hanafy, H. Gabr, A. Ibrahim and A.A.F.A. Gab-Allah. 2004. Status of the sea cucumber fishery in the Red Sea - the Egyptian experience. FAO Fisheries Technical Paper No. 463. 425 p. In: Advances in Sea Sucumber Aquaculture and Management, A. Lovatelli, C. Conand, S. Purcell, S. Uthicke, J.F. Hamel and A. Mercier (Editors), pp 79-90. Geneva: FAO Fisheries Technical Paper.

Mercier, A., S.C. Battaglene and J.F. Hamel. 2000. Periodic movement, recruitment and size-related distribution of the sea cucumber Holothuria scabra in Solomon Islands. Hydrobiologia 440: 81-100.

Mmbaga, T.K. and Y.D. Mgaya. 2004. Sea cucumber fishery in Tanzania: identifying the gaps in resource inventory and management In: Advances in Sea Sucumber Aquaculture and Management, A. Lovatelli, C. Conand, S. Purcell, S. Uthicke, J.F. Hamel and A. Mercier (Editors), pp 193-203. Geneva: FAO Fisheries Technical Paper.

Pitt, R. and N.D.Q. Duy. 2004. Length-weight relationship for sandfish, Holothuria scabra. SPC Beche de mer Information Bulletin 19:39-40.

Rasolofinirina, R. and M. Jangoux. 2004. Sea cucumber fishery and mariculture in Madagascar.
A case study of Toliora, south-west of Madagascar. In: Advances in Sea Sucumber Aquaculture and Management, A. Lovatelli, C. Conand, S. Purcell, S. Uthicke, J.F. Hamel and A. Mercier (Editors), pp 133-149. Geneva: FAO Fisheries Technical Paper.

Shelly, C. 1981. Aspects of the distribution, reproduction, growth and fishery potential of holothurians in the Papuan coastal lagoon. MSc thesis, University of Papua New Guinea.

Uthicke, S. 1997. The seasonality of asexual reproduction in Holothuria (Halodeima) atra, Holothuria (Halodeima) edulis and Stichopus chloronotus (Holothuroidea: Aspidochirotida) on the Great Barrier Reef. Marine Biology 129: 435-441.

Uthicke, S. and J.A.H. Benzie. 2000. Effect of beche-de-mer fishing on densities and size structure of Holothuria nobilis (Echinodermata: Holothuroidea) populations on the Great Barrier Reef. Coral Reefs 19:271-276.

Uthicke, S. and C. Conand. 2005. Local examples of beche-de-mer overfishing: An initial summary and request for information. SPC Beche-de-mer Information Bulletin 21:9-14.

Received: June 2007

Accepted: October 2007 